\title{
Trends in precipitation and streamwater chemistry in East Creek watershed in southwestern British Columbia, 1971-2008
}

\author{
Michael C. FELLER \\ Forest Sciences Department, University of British Columbia, 3041-2424 Main Mall, Vancouver, BC V6T 1Z4, Canada \\ e-mail: feller@interchange.ubc.ca
}

\begin{abstract}
Bulk precipitation and streamwater in a small, undisturbed, forested watershed in southwestern British Columbia were sampled regularly and analyzed for dissolved chemical constituents from 1971 to 2008. Concentrations and fluxes of most chemicals in precipitation and streamwater have exhibited considerable yearly variation. Temporal trends, when they have occurred, have rarely been consistent for the entire 1972-2008 time period. Precipitation has exhibited a decline in electrical conductivity, a decline in $\mathrm{NH}_{4}$, inorganic- $\mathrm{N}$, and total- $\mathrm{N}$ concentrations and fluxes since the 1980s, an increase in $\mathrm{pH}$, a decline in acid $\mathrm{H}$ fluxes since $\sim 1990$, and a decrease in $\mathrm{SO}_{4}$ concentrations and fluxes from 1980 until the late 1990s. Streamwater has exhibited an increase in $\mathrm{NO}_{3}$ concentrations and fluxes until the late 1990s, an increase in $\mathrm{pH}$ and decrease in acid $H$ fluxes since the early 1990s, a decrease in $\mathrm{SO}_{4}$ concentrations and fluxes from $\sim 1980$ until $\sim 2000$, and increases in Na and Cl concentrations and fluxes until $\sim 2000$. Critical precipitation $\mathrm{SO}_{4}$ and inorganic-N loads have probably been exceeded for most years. East Ck. watershed has continuously experienced net inflows of all forms of $\mathrm{N}$ and acid $\mathrm{H}$, and net outflows of dissolved $\mathrm{Si}, \mathrm{Na}, \mathrm{Mg}$, and Ca. Net inflows of inorganic forms of $N$ and total-N have decreased since the early 1980s. Net acid H inflows have decreased since the early 1990s, while net Na and $\mathrm{Cl}$ outflows increased until $\sim 2000$. The contribution of nutrient cycling processes within the watershed to the changes is currently unknown.
\end{abstract}

Key words: British Columbia, nitrogen, nutrients, precipitation chemistry, streamwater chemistry, sulphur, Canada

\section{INTRODUCTION}

Awareness of the potential impacts of altered precipitation chemistry, particularly $\mathrm{N}$ and $\mathrm{S}$, on acidification and eutrophication of streams (Stoddard 1994; Schindler et al. 2006) and attempts to reduce anthropogenic influences on precipitation chemistry (e.g., Nizich et al. 1995) have resulted in recent assessments of the longer term ( $>5$ year) trends in precipitation and the chemistry of small streams (e.g., Edmonds \& Blew 1997; Stottlemyer 1997; Driscoll et al. 1998; Clow \& Mast 1999; Beall et al. 2001; Wright et al. 2001; Watmough \& Dillon 2003; Rogora 2007; Clair et al. 2008). In the northern hemisphere, $\mathrm{SO}_{2}$ and $\mathrm{NO}_{\mathrm{x}}$ emissions to the atmosphere, and fluxes in precipitation, in the $20^{\text {th }}$ Century increased until the 1970s, followed by declines in $\mathrm{SO}_{2}$ emissions, and a levelling off or declines in $\mathrm{NO}_{\mathrm{x}}$ emissions (e.g., Nizich et al. 1995; Clow \& Mast 1999; Rogora 2007). In western Canada, $\mathrm{NO}_{\mathrm{x}}$ emissions have been increasing and are projected to increase further (Schindler et al. 2006), consistent with increasing $\mathrm{NO}_{3}$ concentrations in precipitation in the adjacent northwestern U.S. (Nilles \& Conley 2001). This has resulted in increases, followed by a levelling or decline in streamwater $\mathrm{SO}_{4}$ fluxes (e.g., Likens et al. 1996; Driscoll et al. 1998; Clow \& Mast 1999; Stoddard et al. 1999). The response of streamwater $\mathrm{N}$ fluxes to these changes in precipitation $\mathrm{N}$ fluxes has been more variable. Streamwater $\mathrm{NO}_{3}$ fluxes have sometimes contin- ued to increase in the absence of increased $\mathrm{NO}_{\mathrm{x}}$ emissions (e.g., Stoddard \& Murdoch 1991). They have also decreased (e.g., Likens et al. 1996) or have shown no trend (e.g., Edmonds \& Blew 1997). This may be due to the extent to which a watershed has become nitrogen saturated (cf. Stoddard 1994) by precipitation (e.g., Fenn et al. 1998; Lovett et al. 2000). In the absence of significant $\mathrm{N}$ saturation, precipitation $\mathrm{N}$ concentrations are unlikely to have a major impact on streamwater chemistry as $\mathrm{N}$ is removed from and released to solution by numerous biological and chemical processes which are controlled by factors unrelated to precipitation $\mathrm{N}$ chemistry (Feller 2005).

Precipitation in southwestern British Columbia, east of the city of Vancouver, has been acidic with elevated levels of $\mathrm{SO}_{4}$ and $\mathrm{NO}_{3}$ (Feller 1987; Schindler et al. 2006). Within this area, precipitation and streamwater chemistry have been monitored almost continuously since 1972 for studies assessing the impacts of forestry operations on streams. (Feller \& Kimmins 1984; Feller 1987). In view of a) concerns about impacts on watersheds and stream eutrophication of elevated nitrogen levels in precipitation (e.g., Stoddard 1994; Vitousek et al. 1997); and b) the prediction that atmospheric nitrogen levels will continue to increase (Galloway et al. 1995), knowledge of recent trends in precipitation and streamwater chemistry, and the extent of any relationships between the two in western North America is highly desirable. 
In western North America, longer term studies are scarce; Martin \& Harr (1988) reported 12-16 year (1969-1985) precipitation and streamwater chemistry data for the H.J. Andrews Experimental Forest in western Oregon, but overall average chemistry, rather than yearly variation, was discussed. Edmonds \& Blew (1997) and Edmonds et al. (1998), however, have reported 10 year trends (1984-1993) in precipitation and streamwater chemistry in a relatively undisturbed watershed in Washington's Olympic Peninsula. Assessments for longer periods and in areas where precipitation chemistry already displays significant anthropogenic influences do not appear available. The present study provides such an assessment of trends in precipitation and stream chemistry from 1972 to 2008 for an undisturbed forested watershed in southwestern British Columbia. Nitrogen and $\mathrm{S}$ chemistry is emphasized. The $\mathrm{N}$ and S chemistry of 3 other streams is used to indicate the generality of stream chemistry trends in the study area.

\section{METHODS}

\subsection{The study area}

East $\mathrm{Ck}$. and the other study watersheds occur in the southern half of the University of British Columbia Research Forest, approximately $40 \mathrm{~km}$ east of Vancouver, within the Dry Maritime Coastal Western Hemlock (CWHdm) biogeoclimatic subzone (Meidinger \& Pojar 1991). The area has a marine warm temperate rainy climate with an annual precipitation of usually 1700-2800 $\mathrm{mm}$, approximately $50 \%$ of which falls from October through January, and $10 \%$ in summer (June-August). Due to the low elevation (140-450 m), snow falls only occasionally, mainly during December-March, and most precipitation is rain. Temperatures are mild, with an average daily mean of $17{ }^{\circ} \mathrm{C}$ for the warmest month (July) and $2{ }^{\circ} \mathrm{C}$ for the coldest month (January). The soils are of glacial origin and are primarily shallow (50$150 \mathrm{~cm}$ ), coarse-textured Humo-Ferric Podzols (Soil Classification Working Group 1988). The topography varies from flat to hilly and gently rolling, with occasional bedrock knolls. The bedrock consists predominantly of quartz diorite. East Ck. lies in a V-shaped valley and has a streambed dominated by inorganic rock, gravel, and sand ( $80-85 \%$ cover).

The watersheds are covered with mixed western hemlock (Tsuga heterophylla (Raf.) Sarg.), western redcedar (Thuja plicata Donn.), and Douglas-fir (Pseudotsuga menziesii (Mirb.) Franco) forests with small amounts of red alder (Alnus rubra Bong.), big-leaf maple (Acer macrophyllum Pursh), and western paper birch (Betula papyrifera Marsh.). Understories are relatively sparse in the mostly closed canopy forests and consist mainly of shrubs and mosses.

East Ck. watershed, 44 ha in size, was covered primarily with forests that had regenerated naturally after a fire in 1968. Data were also collected from two water- sheds (Marc Ck. (23 ha), and Middle Ck. (16 ha)) that were covered primarily with the same forests as East Ck. watershed, and another watershed (South Ck. 19 ha) that was covered with forests that regenerated naturally after clearcutting and slashburning in the early 1930s. Marc, Middle, and South Ck. watersheds were subjected to varied forestry operations (clearcutting, herbiciding, and burning) during the course of the study. Of Marc Ck watershed's 23 ha, 14 were clearcut in 1973, herbicided and burned in 1987-88, then planted with Douglas-fir seedlings in 1989. Middle Ck. watershed was clearcut and burned in 1983-84, then planted with Douglas-fir and western red cedar in 1985. South Ck. watershed was logged in 1999. Data presented in this paper are for time periods when the stream chemistry in these watersheds was considered not to be affected by forest operations based on statistical analyses described by Feller \& Kimmins (1984). These periods are 1992-2008 for Marc Ck., 1991-2008 for Middle Ck., and 1986-1998 for South Ck.

\subsection{Water quantities}

Precipitation has been measured by a network of up to 6 tipping-bucket gauges located in and within $1 \mathrm{~km}$ of the watersheds. The gauges have been run by the Research Forest as well as by various researchers. Watershed precipitation was estimated from the gauge network using the isohyetal method.

East Ck. streamflow was measured initially using a calibrated rectangular broad-crested weir. Measurements at this weir were found to underestimate water drainage from the watershed (C Ck. of Feller \& Kimmins 1979). The weir was reconstructed after 3 years. Unmeasured drainage has subsequently been found to be negligible.

\subsection{Water chemistry}

Incident bulk precipitation for chemical analysis was collected in simple polyethylene systems, each consisting of a funnel containing a plug of spun fibreglass connected to a $4 \mathrm{~L}$ polyethylene container via a rubber stopper. Each collector was located such that the top of the funnel was $40-70 \mathrm{~cm}$ above the soil surface and above any nearby vegetation. A total of 4 precipitation collectors were established in pairs. Each pair has been moved around within an area of $2 \mathrm{~km}$ diameter, so that the collectors have remained in forest openings and have not been influenced by forest trees. Each precipitation collector has been emptied regularly or whenever possible during dry periods. A sample for chemical analysis was taken from each collector whenever it was emptied. Samples were collected in acid rinsed and prewashed polyethylene bottles. Precipitation collectors were emptied at 2-4 week intervals from 1971 to 1978, then at $1-2$ week intervals since 1979 . Only 15 samples were collected during the 1978-79 water year, so data for this year are not presented. 
Samples of streamwater for chemical analysis were collected once every 1-2 weeks, and occasionally more frequently, immediately upstream of the ponds behind the weirs. Samples were collected in acid rinsed and prewashed polyethylene bottles.

Water samples collected in the field were taken to the laboratory where $\mathrm{pH}$ and electrical conductivity were measured as soon as possible - usually within 4 hours of collection, which tests had indicated would give the same results as measurements made in the field. Electrical conductivity was measured using a Radiometer CDM2e conductivity meter, and all measurements were corrected to $25{ }^{\circ} \mathrm{C}$. $\mathrm{pH}$ was measured with an Orion model 404 specific ion meter with standard glass and $\mathrm{Ag} / \mathrm{AgCl}$ reference electrodes.

After these analyses were completed, samples were filtered $(0.45 \mu \mathrm{m})$ if visible turbidity was present. Turbidity was visible when it was measured as $>0.3$ NTU. Tests of 0.3 NTU samples showed no consistent differences and no differences $>8 \%$ in ion concentrations between filtered and unfiltered samples. Samples were not filtered prior to 1986. As few samples have measurable turbidity (23 East Ck. and 22 South Ck. samples of a total of 460 samples from each stream during an approx. 14 year period had turbidity $>0.3$ NTU), errors due to lack of filtering in the 1972-1985 period are likely to be only minor.

Water samples were then stored either frozen or refrigerated at $4{ }^{\circ} \mathrm{C}$ for periods up to 10 weeks when they were analyzed for cations and anions. Tests had shown no consistent or major ( $>15 \%)$ effects of storage for 10 weeks on any of the subsequently measured ion concentrations.

Ammonium and anion $\left(\mathrm{NO}_{3}, \mathrm{SO}_{4}, \mathrm{Si}\right.$, and $\left.\mathrm{Cl}\right)$ concentrations were measured colorimetrically using a Technicon Autoanalyzer ${ }^{\mathrm{TM}}$ II using standard colorimetric methods as described in Feller (1977). Beginning in April, 1983, anions and $\mathrm{NH}_{4}$ were measured by ion chromatography using a Dionex $2110 \mathrm{i}$ instrument. This continued until June, 1987, when anions, as well as $\mathrm{NH}_{4}$ were again measured using the same colorimetric methods as previously, but using a Technicon TRAACS 800 continuous flow analysis instrument. Metallic cation $(\mathrm{K}, \mathrm{Na}, \mathrm{Mg}$, and $\mathrm{Ca}$ ) concentrations were measured by atomic absorption spectrophotometry, using a Varian Techtron AA5 instrument until 1991, and thereafter using a Varian SpectrAA 10 instrument.

Electrical conductivity and $\mathrm{pH}$ analyses began in 1971, while other chemical analyses, except organic-N, began in 1972. Organic-N was measured beginning in July, 1981 using an alkaline persulphate digestion method (D'Elia et al. 1977). The $\mathrm{NO}_{3}$ produced from the digestion was analyzed as described above.

\subsection{Chemical fluxes in precipitation and streamwater}

Chemical fluxes in precipitation were calculated by multiplying precipitation volume during a sampling interval by the concentration of a chemical measured in the precipitation sample collected at the end of that sampling interval. Results were expressed on a $\mathrm{kg} \mathrm{ha}^{-1}$ basis. Chemical fluxes in streamwater were calculated in a similar fashion, except that the streamwater volume, to which the chemical concentrations measured on day $\mathrm{X}$ were applied, was considered to be the volume of water flowing over the weir from a time halfway between day $\mathrm{X}$ and the previous sampling day, to a time halfway between day $\mathrm{X}$ and the next sampling day. Results were again expressed on a $\mathrm{kg} \mathrm{ha}^{-1}$ basis. Annual streamwater chemical fluxes calculated this way for East Ck. generally differed by $<12 \%$ from those calculated by applying concentration - discharge relationships to measured discharge. It should be noted that $\mathrm{NO}_{3}, \mathrm{NH}_{4}$ and $\mathrm{SO}_{4}$ concentrations are for those chemical species but the corresponding fluxes are given for $\mathrm{NO}_{3}-\mathrm{N}, \mathrm{NH}_{4}-\mathrm{N}$, and $\mathrm{SO}_{4}-\mathrm{S}$.

\subsection{Data analysis}

Annual water quantity and chemistry data are presented on a water year (1 October-30 September) basis. Mean volume weighted values of chemical parameters were calculated on an annual basis. The weighted $\mathrm{pH}$ values were calculated by initially converting $\mathrm{pH}$ to $\mathrm{H}$ ion concentrations, calculating the mean volume weighted $\mathrm{H}$ ion concentration, then converting this back to a $\mathrm{pH}$ value. Annual trends in concentrations were assessed using volume-weighted concentrations, as both streamwater (Feller \& Kimmins 1979) and precipitation chemical concentrations often varied inversely with water volume.

To assess the influence of anthropogenic sources on precipitation $\mathrm{SO}_{4}$ and $\mathrm{N}$ levels, excess $\mathrm{SO}_{4}$ and $\mathrm{N}$ concentrations (in excess over those expected from seawater) were calculated using the method described by Cogbill \& Likens (1974).

Temporal trends in annual concentrations and fluxes could not be assessed using conventional non parametric analyses, such as the seasonal Kendall test, due to problems with serial correlation and the frequent existence of non-linear trends. To assess factors which might have influenced chemical fluxes, relationships between chemical parameters and water volumes were assessed using Pearson correlation analyses. The level of statistical significance was set at $p=0.05$. All statistical analyses were conducted using SYSTAT 11.

\subsection{Quality control}

Over the years many people were involved in conducting the chemical analyses. Fewer people (4) have actually conducted the field sampling and measured $\mathrm{pH}$ and electrical conductivity. The accuracy of all chemical analyses was checked by regularly submitting multiple samples, and/or dilutions, of the same solution for analysis. Occasional discrepancies of $>10 \%$ were 

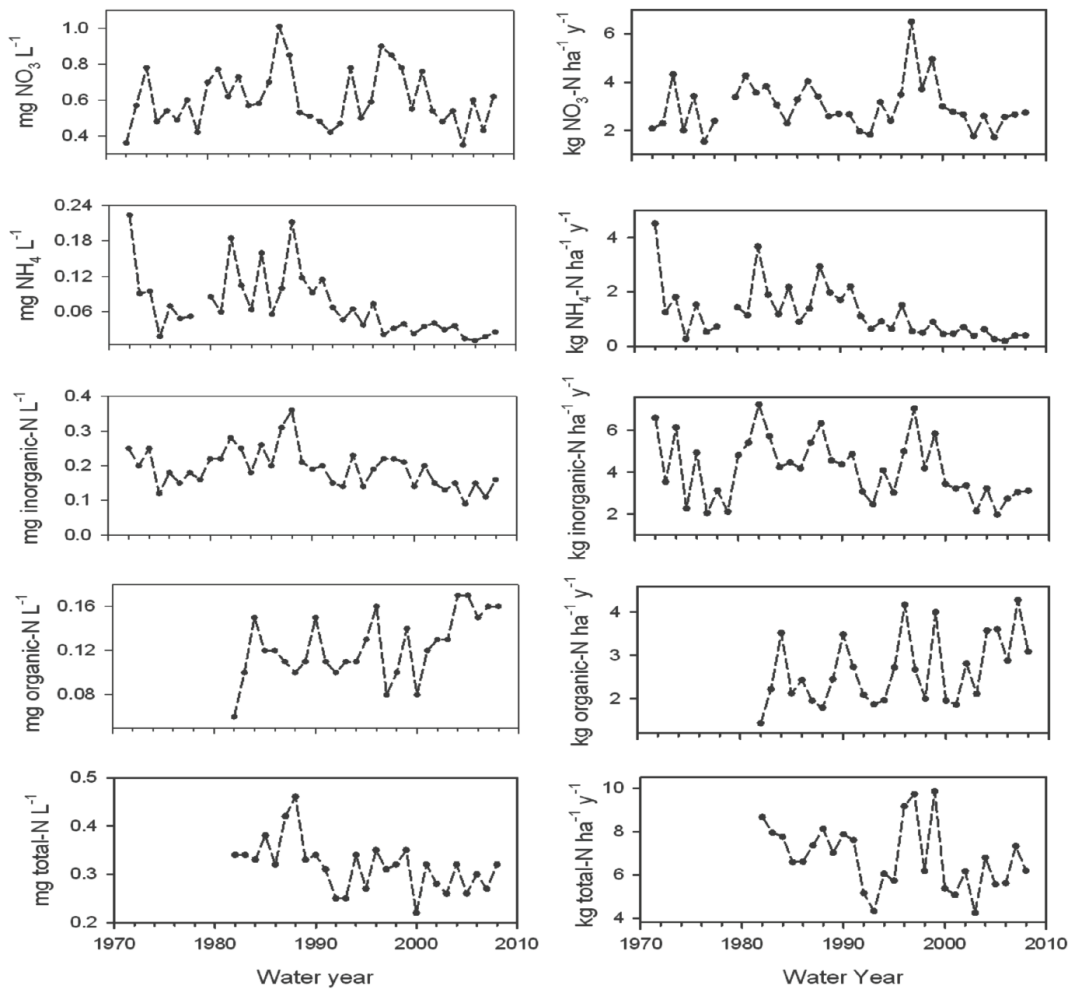

Fig. 1. Mean annual weighted $N$ concentrations and fluxes for precipitation in the study area for the 1971-72 (1972) to 2007-08 (2008) water years.

resolved through repeated analysis of the sample in question.

During the changes from the Technicon AutoAnalyzerTM II to the Dionex $2110 \mathrm{i}$ and from the Dionex $2110 \mathrm{i}$ to the Technicon TRAACSTM 800 instruments, large numbers of samples were analyzed for all ions on both pairs of instruments. No significant or consistent differences were found.

Streamwater volumes in East Ck. have been estimated using a height-discharge calibration equation and continuous measurements of stream height at the weir. Since stream height measurements began, there have been no days, outside the 1978-79 water year, on which all water height recorders for East $\mathrm{Ck}$ and 3-7 other instrumented streams have not worked, so it has always been possible to develop regression equations to replace missing height data for East Ck. weir using data from another weir. Excluding the 1978-79 water year, the number of days with missing data has been $<2 \%$ of the total number.

Data presented here differ slightly from data presented previously by Feller \& Kimmins (1984) and Feller (1987). In these previous papers, mean weighted concentrations were calculated on a monthly basis, averaging concentrations per month and weighting these averages by monthly precipitation or streamflow volumes. In the present analysis, weighting was done on a sampling interval (usually 1-2 weeks) basis, so data here are considered to be more accurate.
Measurements of low concentrations, near detection limits, are prone to relatively high percentage errors, although absolute errors will be small. Ammonium concentrations in streamwater and Si concentrations in precipitation were almost invariably close to, or below, the detection limit $\left(0.01 \mathrm{mg} \mathrm{L}^{-1}\right)$ and annual streamwater $\mathrm{NH}_{4}$ and precipitation Si fluxes were nearly always $<0.1$ $\mathrm{kg} \mathrm{ha}^{-1}$. These concentrations and fluxes are not presented here, although they are included in inorganic- $\mathrm{N}$ and total-N concentrations and fluxes and watershed $\mathrm{N}$ and Si budgets.

\section{RESULTS}

\subsection{Precipitation chemistry}

Calculation of excess $\mathrm{SO}_{4}$, and a similar one for $\mathrm{N}$, indicated sea salt deposition accounted for $5-15 \%$ of the $\mathrm{SO}_{4}$ in bulk precipitation and a negligible amount of $\mathrm{N}$. Chemical concentrations and fluxes generally exhibited high year-to-year variation. Apparent trends in precipitation chemistry with time were a decrease in $\mathrm{NH}_{4}$, inorganic-N, and total-N concentrations and fluxes since the 1980 s, a general increase in $\mathrm{pH}$, beginning noticeably in the mid 1990s and recently averaging approximately $0.05 \mathrm{pH}$ units per year, and a decrease in $\mathrm{SO}_{4}$ concentrations from 1980 to the mid 1990s (Fig. 1 and 2). Acid H fluxes have decreased since 1972, at an average rate of approximately $0.12 \mathrm{~kg} \mathrm{ha}^{-1} \mathrm{y}^{-1}$ (Fig. 2). Nitrate concentrations may have increased until the late 

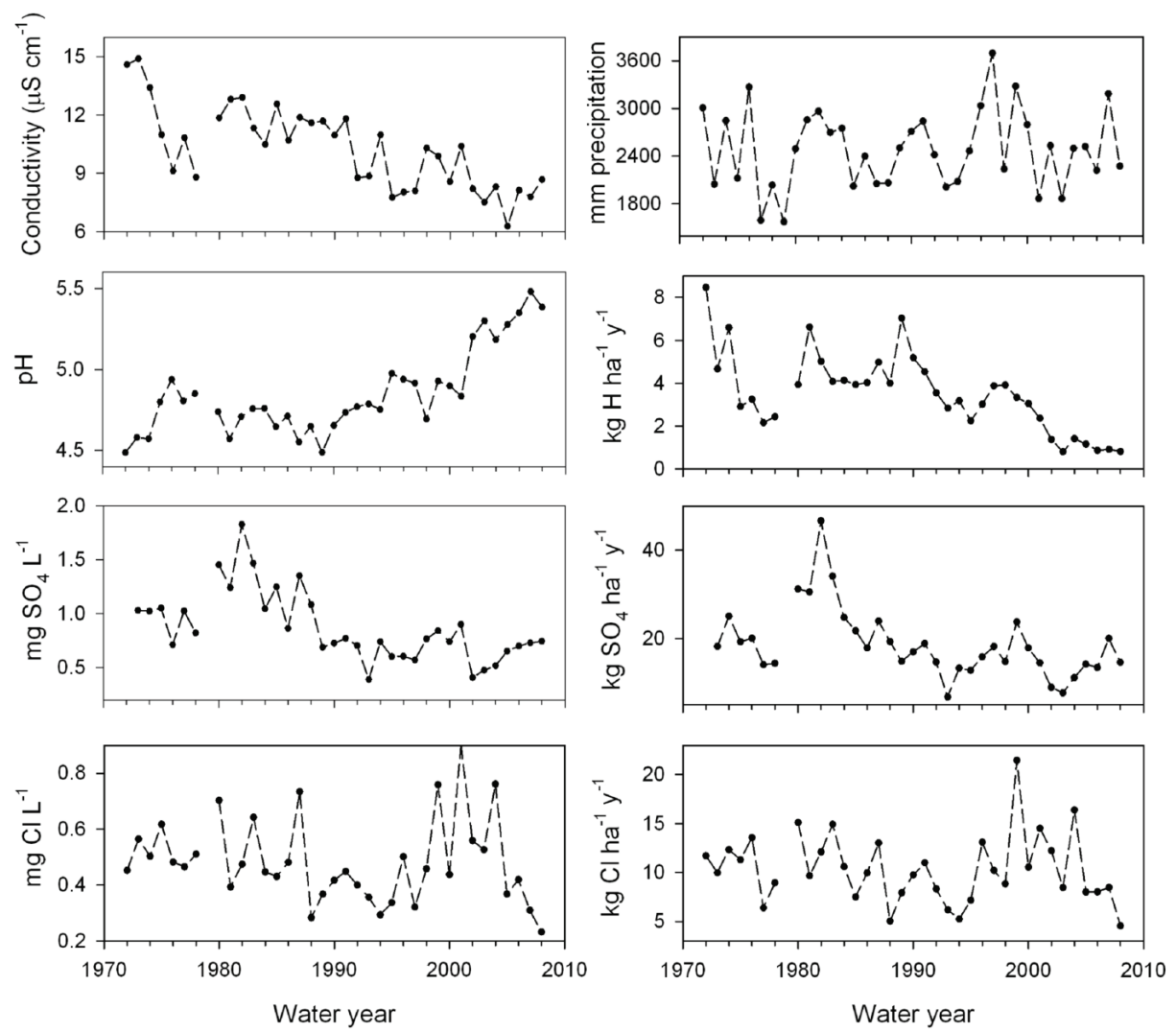

Fig. 2. Annual amount and mean annual weighted $\mathrm{pH}$, electrical conductivity, $\mathrm{H}$ fluxes, and $\mathrm{SO}_{4}$ and $\mathrm{Cl}$ concentrations and fluxes for precipitation in the study area for the 1971-72 (1972) to 2007-08 (2008) water years.

1990s, but have subsequently decreased, although trends are obscured by high year-to-year variation (Fig.1). Precipitation electrical conductivity has generally decreased (Fig. 2). Magnesium and $\mathrm{Ca}$ concentrations and fluxes appear to have declined with time, while $\mathrm{K}$, $\mathrm{Na}$, and $\mathrm{Cl}$ concentrations and fluxes exhibited no obvious trends (Figs 2 and 3). The absence of any consistent trend in $\mathrm{Cl}$ fluxes, and also $\mathrm{Na}$ fluxes indicates that the sea salt contribution to precipitation chemical content has also exhibited no consistent trend, as precipitation $\mathrm{Na}$ content is used to estimate precipitation chemical content from sea salt. The precipitation molar N/S ratio increased until the early 2000 s before possibly declining (Fig. 4).

Annual mean weighted $\mathrm{N}$ and $\mathrm{SO}_{4}$ concentrations tended to be better correlated with precipitation $\mathrm{pH}$ and electrical conductivity than with other chemical concentrations (Tab. 1). Correlations with $\mathrm{pH}$ were negative (Tab. 1). Precipitation $\mathrm{pH}$ was best correlated with precipitation electrical conductivity and $\mathrm{SO}_{4}$ and $\mathrm{N}$ concentrations (Tab. 1). Of the metallic cations, $\mathrm{pH}$ was significantly correlated (negatively) only with $\mathrm{Mg}$ (Tab. 1). No chemical parameter was significantly correlated with precipitation quantity. Sulphate concentrations were best correlated with forms of inorganic- $\mathrm{N}$ and $\mathrm{pH}$, and to a lesser extent with $\mathrm{Na}$ and $\mathrm{Mg}$ concentrations (Tab. 1).

\subsection{Streamwater chemistry}

Streamwater $\mathrm{NO}_{3}$ and inorganic-N concentrations and fluxes have tended to increase with time, although there has been substantial year-to-year variation and there may have been a recent decline in $\mathrm{NO}_{3}$ concentrations (Fig. 5). The increase in streamwater inorganic-N fluxes was primarily due to an increase in streamwater $\mathrm{NO}_{3}$ fluxes (Fig. 5). Organic-N concentrations and fluxes and total-N concentrations have also fluctuated substantially from year to year, but have exhibited no consistent trends, while total-N fluxes appear to have increased since the late 1980s (Fig. 5). Electrical conductivity, streamflow, and Si concentrations and fluxes have exhibited no consistent trends (Fig. 6), while streamwater $\mathrm{pH}$ has tended to increase with time. The increasing $\mathrm{pH}$ has meant a decrease in the relatively small streamwater $\mathrm{H}$ flux with time (Fig. 6). As with precipitation, streamwater $\mathrm{SO}_{4}$ concentrations and fluxes have also tended to decrease from the early 1980s to the mid 1990s (Fig. 6). The molar N/S ratio has followed a similar, but less pronounced trend to the precipitation N/S ratio, increasing to the early 2000s then possibly declining (Fig. 4). Chloride concentrations and fluxes appear to have increased until the early 2000 s (Fig. 6). 

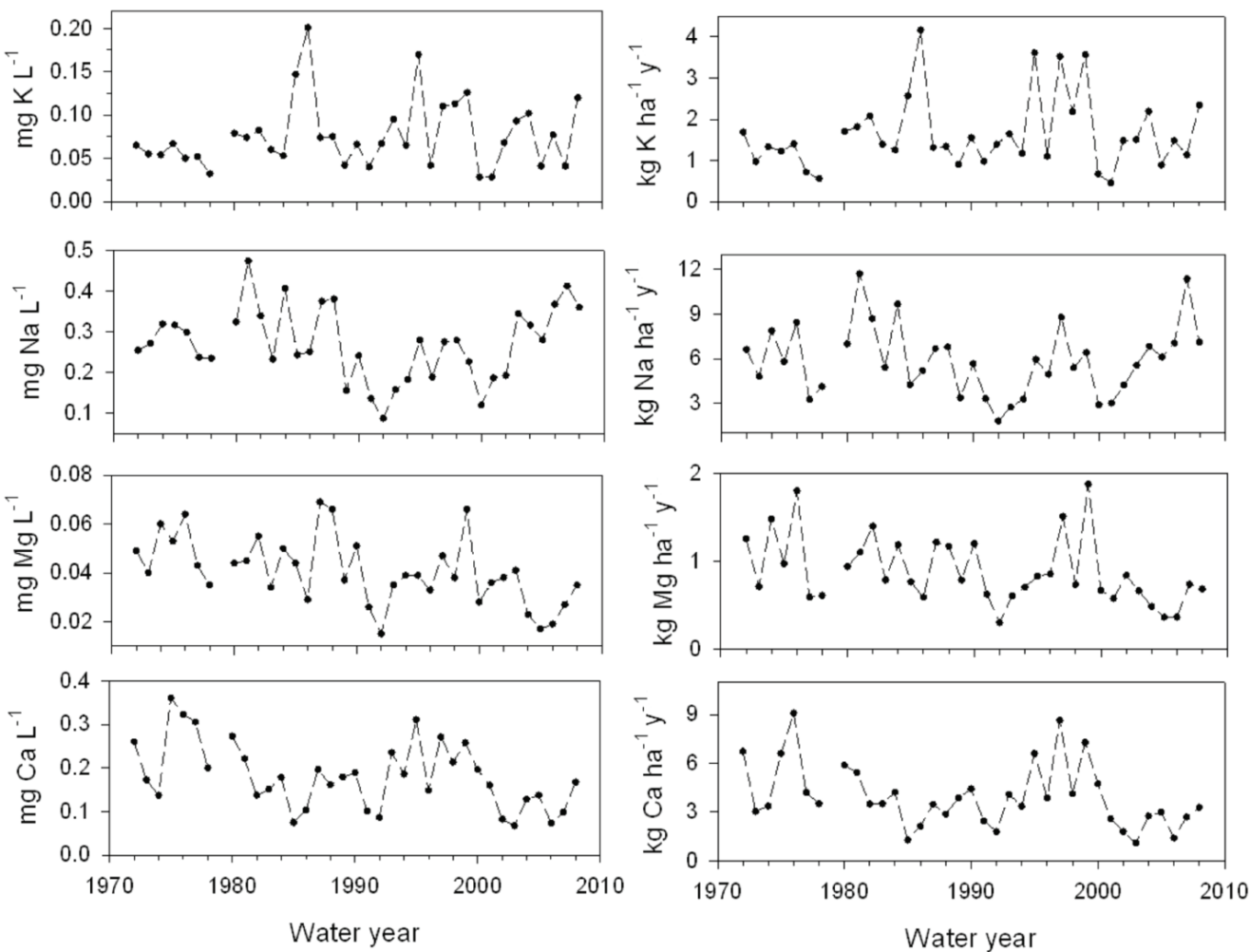

Fig. 3. Mean annual weighted $\mathrm{K}, \mathrm{Na}, \mathrm{Mg}$, and $\mathrm{Ca}$ concentrations and fluxes for precipitation in the study area for the 1971-72 (1972) to 2007-08 (2008) water years.

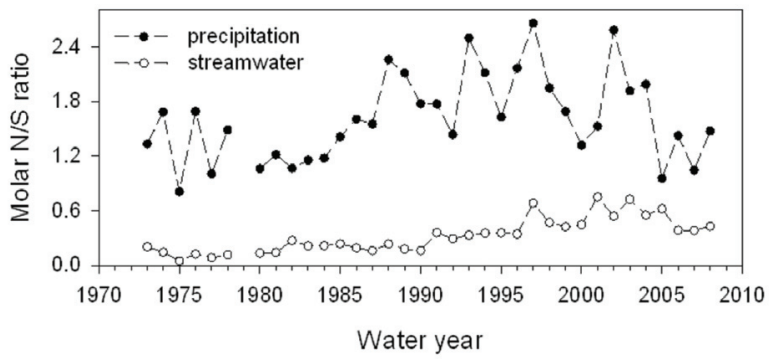

Fig. 4. Annual molar $\mathrm{N} / \mathrm{S}$ ratios (moles of $\mathrm{N}$ in $\mathrm{NH}_{4}+\mathrm{NO}_{3}+$ organic-N) / (moles of $\mathrm{S}$ in $\mathrm{SO}_{4}$ ) in precipitation and East $\mathrm{Ck}$ streamwater for the 1971-72 (1972) to 2007-08 (2008) water years.

Tab. 1. Significant correlations $(p<0.05)$ of precipitation annual mean weighted $\mathrm{pH}$, and $\mathrm{N}$ and $\mathrm{SO}_{4}$ concentrations with other precipitation chemical parameters and precipitation amount. Pearson correlation coefficients are given. EC $=$ electrical conductivity; In-N = inorganic-N; Or-N = organic-N; Tot-N = total-N.

\begin{tabular}{cccccccccccccc}
\hline \multicolumn{2}{c}{$\mathrm{pH}$} & \multicolumn{2}{c}{$\mathrm{NO}_{3}$} & \multicolumn{2}{c}{$\mathrm{NH}_{4}$} & \multicolumn{2}{c}{ Inorganic-N } & \multicolumn{2}{c}{ Organic-N } & \multicolumn{2}{c}{ Total-N } & \multicolumn{2}{c}{$\mathrm{SO}_{4}$} \\
\hline $\mathrm{EC}$ & -0.81 & $\mathrm{Mg}$ & 0.57 & $\mathrm{EC}$ & 0.67 & $\mathrm{pH}$ & -0.68 & $\mathrm{pH}$ & 0.62 & $\mathrm{Mg}$ & 0.68 & $\mathrm{In}-\mathrm{N}$ & 0.62 \\
$\mathrm{In}-\mathrm{N}$ & -0.68 & $\mathrm{pH}$ & -0.42 & $\mathrm{pH}$ & -0.65 & $\mathrm{EC}$ & 0.67 & $\mathrm{EC}$ & -0.45 & $\mathrm{EC}$ & 0.67 & $\mathrm{NH}_{4}$ & 0.59 \\
$\mathrm{NH}_{4}$ & -0.65 & $\mathrm{EC}$ & 0.39 & $\mathrm{SO}_{4}$ & 0.59 & $\mathrm{SO}_{4}$ & 0.62 & $\mathrm{NO}_{3}$ & -0.44 & $\mathrm{SO}_{4}$ & 0.57 & $\mathrm{Tot}-\mathrm{N}$ & 0.57 \\
$\mathrm{Or}_{-} \mathrm{N}$ & 0.62 & $\mathrm{SO}_{4}$ & 0.39 & $\mathrm{Mg}$ & 0.39 & $\mathrm{Mg}$ & 0.61 & $\mathrm{Na}$ & 0.40 & $\mathrm{pH}$ & -0.52 & $\mathrm{pH}$ & -0.51 \\
$\mathrm{SO}_{4}$ & -0.51 & & & & & & & & & & & $\mathrm{NO}_{3}$ & 0.39 \\
$\mathrm{Mg}$ & -0.43 & & & & & & & & & & & $\mathrm{Na}$ & 0.36 \\
$\mathrm{NO}_{3}$ & -0.42 & & & & & & & & & & & & \\
\hline
\end{tabular}



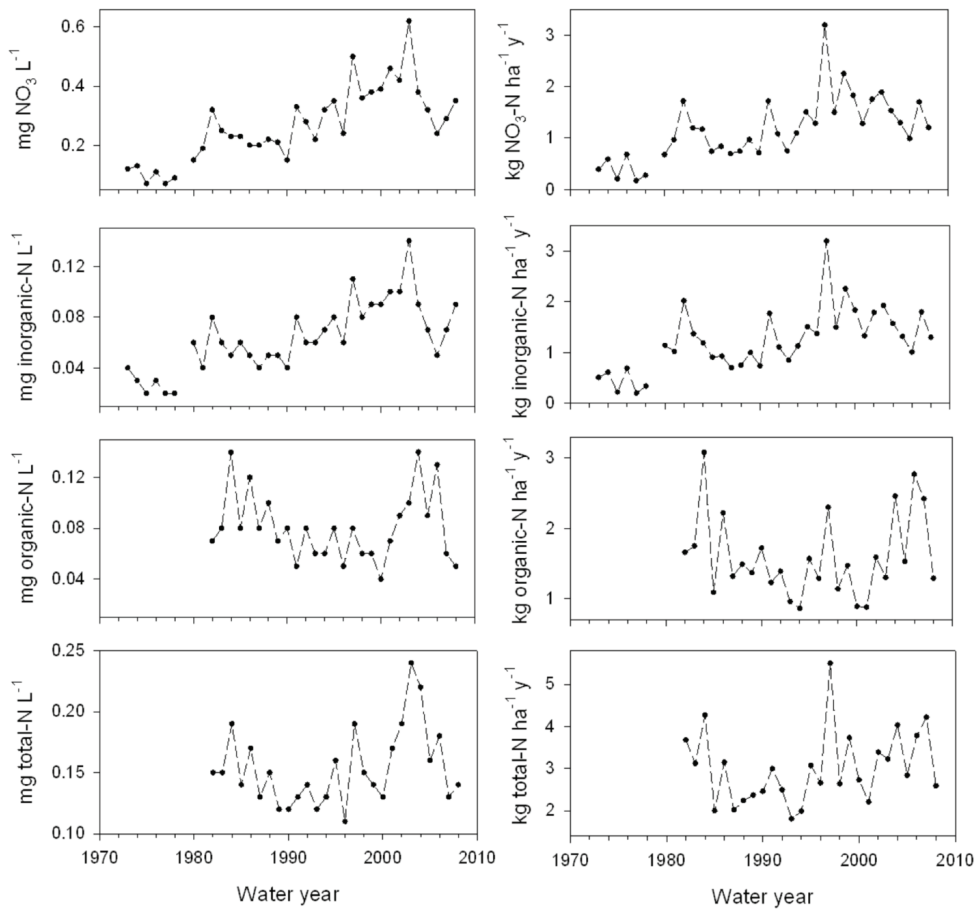

Fig. 5. Mean annual weighted N concentrations and fluxes for East Ck. streamwater for the 1971-72 (1972) to 2007-08 (2008) water years.
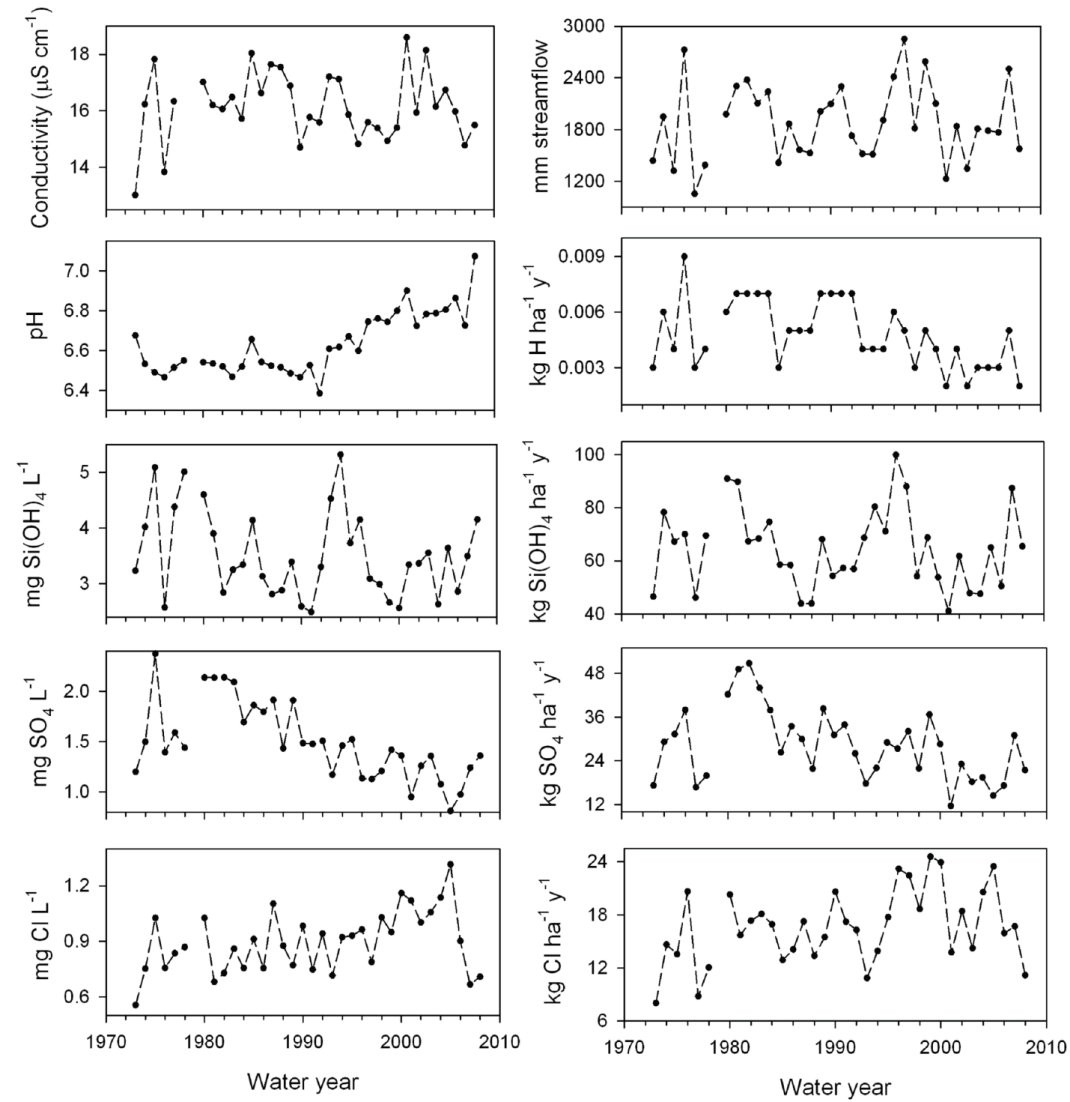

Fig. 6. Annual streamflow and mean annual weighted $\mathrm{pH}$, electrical conductivity, $\mathrm{H}$ fluxes, and dissolved $\mathrm{Si}, \mathrm{SO}_{4}$ and $\mathrm{Cl}$ concentrations and fluxes for East Ck streamwater for the 1971-72 (1972) to 2007-08 (2008) water years. 
Data from the three other streams sampled in the study area also show increases in $\mathrm{NO}_{3}$ and total-N concentrations until the early 2000 s, followed by inconsistent fluctuations, and a general decrease in $\mathrm{SO}_{4}$ concentrations from the mid 1980s until the early 2000s, after which the trend has been unclear (Fig. 7).
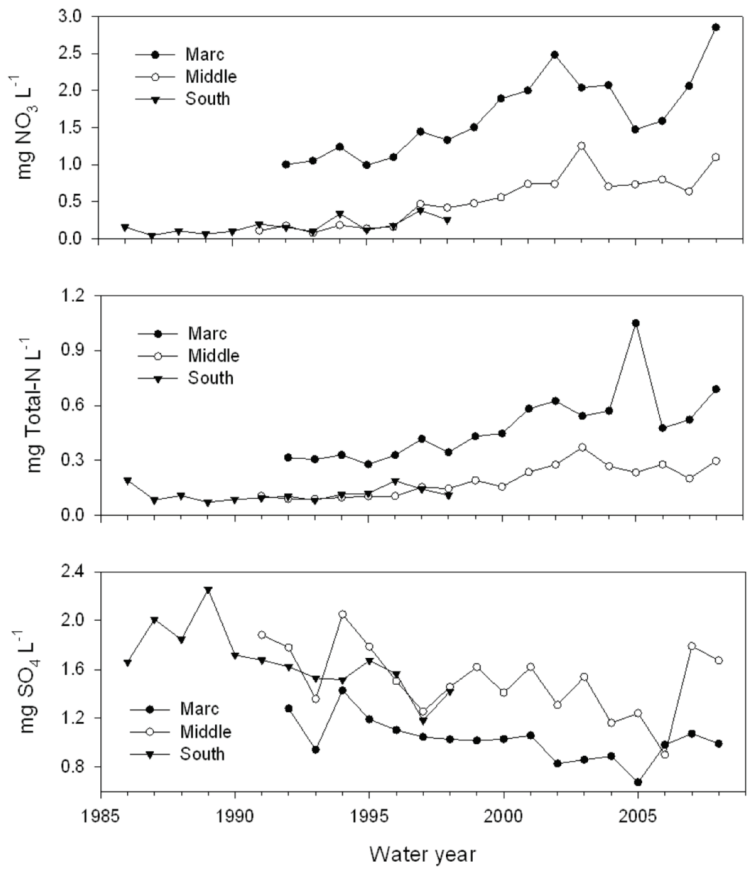

Fig. 7. Mean annual weighted $\mathrm{NO}_{3}$, total-N, and $\mathrm{SO}_{4}$ concentrations, for Marc, Middle, and South $\mathrm{Ck}$ streamwater for periods during the 1985-86 (1986) to 2007-08 (2008) water years when these creeks were considered not to be affected by forestry operations.

Metallic cation concentrations and fluxes have also exhibited substantial year-to-year fluctuations with no consistent trend apparent for $\mathrm{K}$ concentrations and fluxes, and $\mathrm{Mg}$ and $\mathrm{Ca}$ fluxes (Fig. 8). Sodium concentrations and fluxes appear to have increased until around 2000, while $\mathrm{Mg}$ and $\mathrm{Ca}$ concentrations may have decreased with time, but the long term trends have been obscured by substantial year-to-year fluctuations (Figs 6 and 8).

Streamwater $\mathrm{pH}$ was significantly correlated best with streamwater $\mathrm{SO}_{4}$ concentrations (negatively) and with streamwater $\mathrm{NO}_{3}$ concentrations (positively) (Tab. 2 ). With precipitation chemistry, it was significantly correlated best with precipitation $\mathrm{pH}$ (positively) and with precipitation electrical conductivity and $\mathrm{NH}_{4}$ and $\mathrm{SO}_{4}$ concentrations (negatively) (Tab. 2). Streamwater $\mathrm{NO}_{3}$, inorganic- $\mathrm{N}$, total- $\mathrm{N}$, and $\mathrm{SO}_{4}$ concentrations were significantly correlated best with streamwater $\mathrm{pH}$ (positively), while streamwater $\mathrm{SO}_{4}$ concentrations were also significantly correlated with streamwater concentrations of the different forms of inorganic-N (Tab. 2). Streamwater nitrogen and $\mathrm{SO}_{4}$ concentrations were generally also significantly correlated with precipitation $\mathrm{SO}_{4}$ concentrations, $\mathrm{pH}$, and electrical conductivity (Tab. 2).
Streamwater organic-N and total-N concentrations were less well correlated with other streamwater and precipitation chemical parameters than were the different forms of inorganic-N (Tab. 2). It is noteworthy that 1) the best correlation of all was for streamwater $\mathrm{SO}_{4}$ concentrations with precipitation $\mathrm{SO}_{4}$ correlations and 2) there was no significant correlation between any of the streamwater $\mathrm{pH}$ or $\mathrm{N}$ and $\mathrm{SO}_{4}$ concentrations with streamwater quantity (Tab. 2).

\subsection{Watershed budgets}

Annual evapotranspiration (precipitation quantity streamflow quantity) has displayed no significant trend with time (Fig. 9). The net outflow from the watersheds (streamwater output - precipitation input) has fluctuated but has been negative for all $\mathrm{N}$ chemicals studied as well as acid $\mathrm{H}$, suggesting a net inflow of these chemicals into East Ck watershed (Fig. 9). Annual net inflow has been of a similar magnitude for each of $\mathrm{NH}_{4}-\mathrm{N}$, $\mathrm{NO}_{3}-\mathrm{N}$, and organic- $\mathrm{N}$, ranging from 0.1 to $4.4 \mathrm{~kg} \mathrm{~N}$ $\mathrm{ha}^{-1}$, with annual total-N net inflows ranging from 1.7 to $8.0 \mathrm{~kg} \mathrm{~N} \mathrm{ha}^{-1}$ (Fig. 9). On average, $\mathrm{NO}_{3}-\mathrm{N}, \mathrm{NH}_{4}-\mathrm{N}$, and organic-N have contributed $44 \%, 24 \%$, and $31 \%$, respectively, to total net $\mathrm{N}$ inflow. Since the early 1980 s, there appears to have been a trend towards decreasing net inflows of inorganic forms of $\mathrm{N}$ and total-N. Net inorganic-N inflows since 2000 have been consistently among the lowest recorded (Fig. 9). The net inflows in acid H showed no obvious trends from 1972 until the early 1990s, but between then and 2008, these inflows have tended to decrease (Fig. 9).

Net outflows of $\mathrm{SO}_{4}$ have generally occurred, but declines in precipitation inputs of $\mathrm{SO}_{4}$ have been balanced by declines in streamflow outputs so net outflows have not displayed any consistent temporal trend although they might have decreased since the late 1980s (Fig. 9). As with $\mathrm{SO}_{4}$, net outflows of $\mathrm{Cl}$ have also generally occurred, but these have tended to increase with time until $\sim 2000$ (Fig. 9). Net outflows of metallic cations and $\mathrm{Si}$ have invariably occurred, but year-toyear variation has been substantial and no consistent temporal trends are apparent, other than a possible increase in Na net outflow until $\sim 2000$ and a decrease in Ca net outflow since the early 1980s (Figs 9 and 10).

\section{DISCUSSION}

\subsection{Precipitation chemistry}

The present study sampled bulk precipitation, which includes wet and some dry deposition. Accurate estimates of dry deposition in this region of North America do not appear to be available. However, bulk precipitation sampling in the study area may underestimate total (wet + dry deposition) $\mathrm{NH}_{4}, \mathrm{NO}_{3}$, and $\mathrm{SO}_{4}$ concentrations in precipitation by $23-31 \%, 25-28 \%$, and $14-$ 23\%, respectively (DeCatanzaro \& Binkley 1981). Thus, $\mathrm{N}$ and $\mathrm{S}$ deposition in the study area are likely to be greater than indicated in figure 1 . 

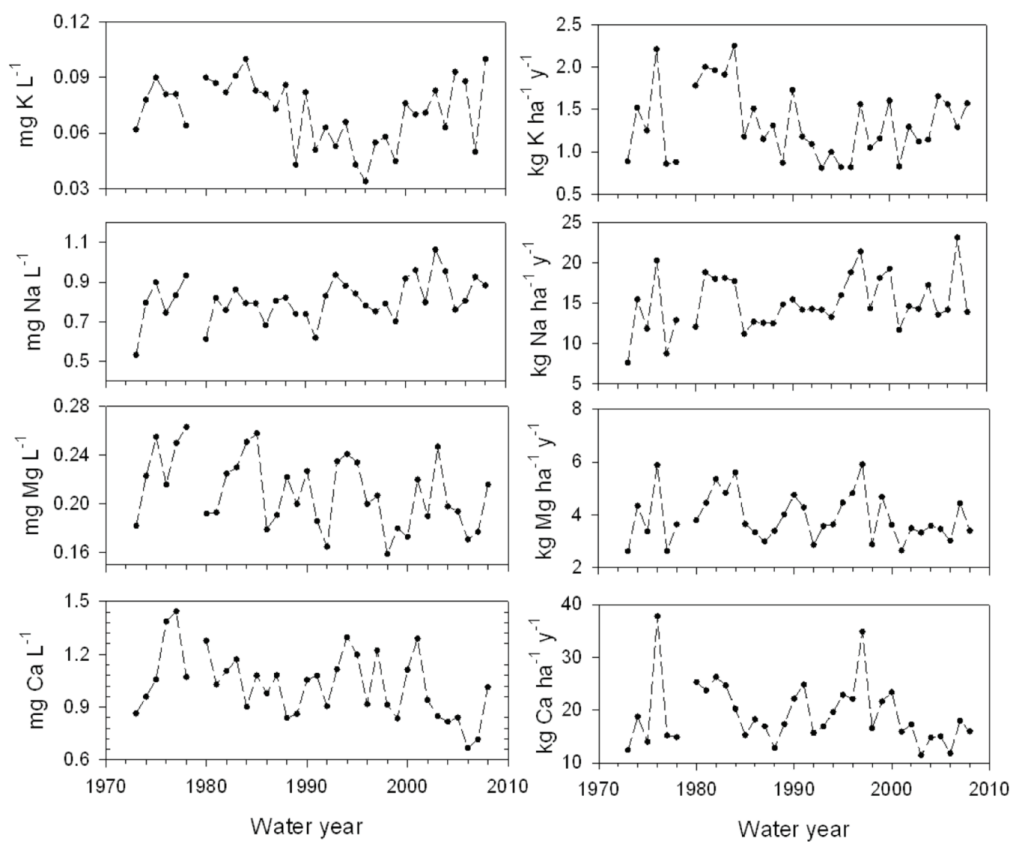

Fig. 8. Mean annual weighted $\mathrm{K}, \mathrm{Na}, \mathrm{Mg}$, and Ca concentrations and fluxes for East Ck. streamwater for the 1971-72 (1972) to 2007-08 (2008) water years.
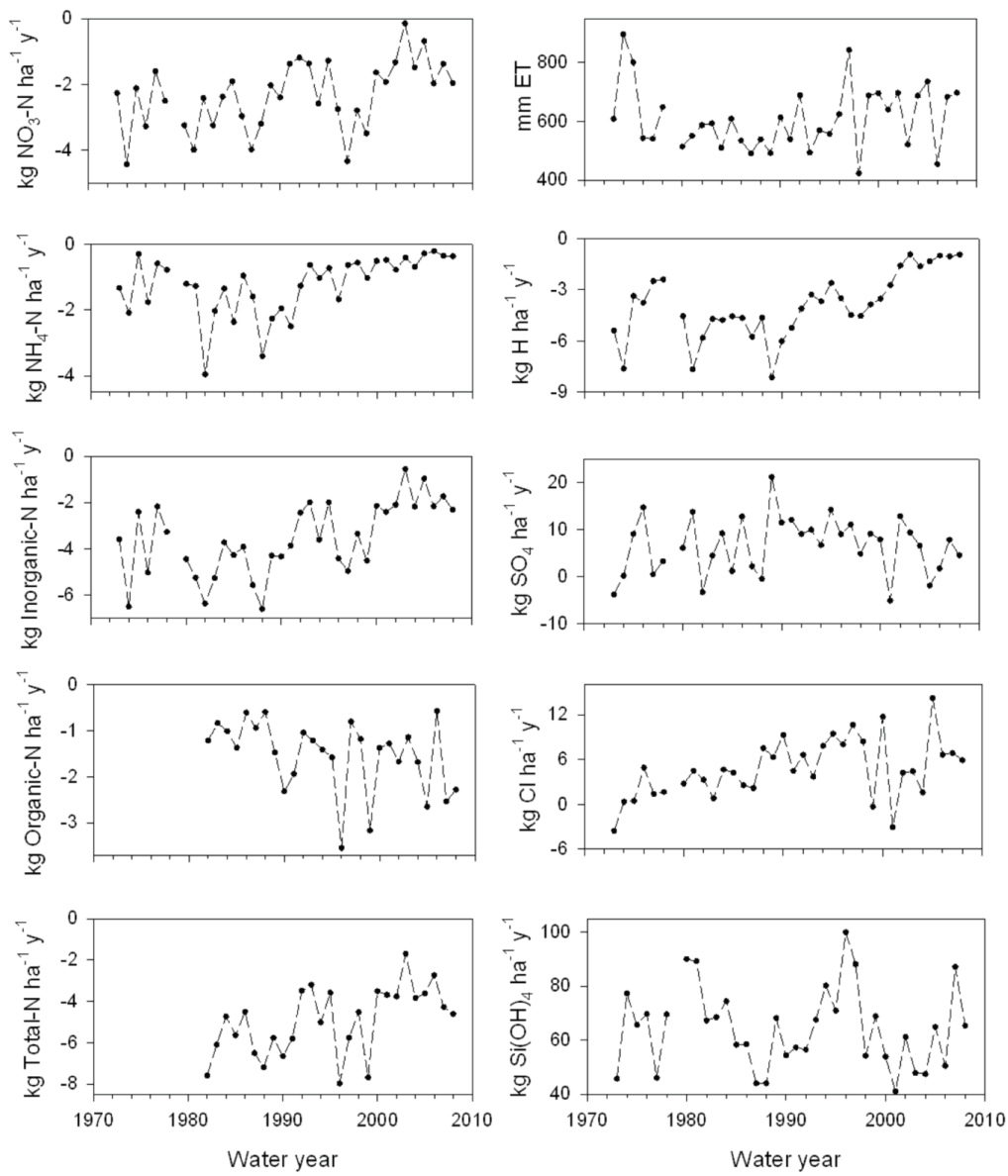

Fig. 9. Annual net outflows (streamwater ouput - precipitation input) of $\mathrm{N}$, acid $\mathrm{H}, \mathrm{SO}_{4}, \mathrm{Cl}$, and dissolved $\mathrm{Si}$ in East $\mathrm{Ck}$ streamwater, as well as annual evapotranspiration (ET) (precipitation quantity - streamflow quantity) for the 1971-72 (1972) to 2007-08 (2008) water years. 
Tab. 2. Significant correlations $(p<0.05)$ of East $\mathrm{Ck}$. streamwater annual mean weighted $\mathrm{pH}$, and $\mathrm{N}$ and $\mathrm{SO}_{4}$ concentrations with other East Ck. streamwater and precipitation annual mean weighted chemical parameters. Pearson correlation coefficients are given.

\begin{tabular}{|c|c|c|c|c|c|c|c|c|c|c|c|c|c|}
\hline \multicolumn{2}{|c|}{$\mathrm{pH}$} & \multicolumn{2}{|c|}{$\mathrm{NO}_{3}$} & \multicolumn{2}{|c|}{$\mathrm{NH}_{4}$} & \multicolumn{2}{|c|}{ Inorganic-N } & \multicolumn{2}{|c|}{ Organic-N } & \multicolumn{2}{|c|}{ Total-N } & \multicolumn{2}{|c|}{$\mathrm{SO}_{4}$} \\
\hline \multicolumn{14}{|c|}{ Correlations with streamwater chemical parameters } \\
\hline $\mathrm{SO}_{4}$ & -0.62 & $\mathrm{pH}$ & 0.59 & $\mathrm{SO}_{4}$ & 0.42 & $\mathrm{pH}$ & 0.58 & $\mathrm{~K}$ & 0.41 & $\mathrm{pH}$ & 0.33 & $\mathrm{pH}$ & -0.62 \\
\hline $\mathrm{NO}_{3}$ & 0.59 & $\mathrm{SO}_{4}$ & -0.45 & $\mathrm{Na}$ & -0.35 & $\mathrm{SO}_{4}$ & -0.38 & & & & & $\mathrm{NO}_{3}$ & -0.45 \\
\hline In-N & 0.58 & $\mathrm{Na}$ & 0.42 & & & $\mathrm{Na}$ & 0.37 & & & & & $\mathrm{NH}_{4}$ & 0.42 \\
\hline $\mathrm{Na}$ & 0.34 & $\mathrm{Cl}$ & 0.35 & & & & & & & & & In- $\mathrm{N}$ & -0.38 \\
\hline \multicolumn{14}{|c|}{ Correlations with precipitation chemical parameters } \\
\hline $\mathrm{pH}$ & 0.66 & $\mathrm{EC}$ & -0.54 & $\mathrm{SO}_{4}$ & 0.56 & $\mathrm{pH}$ & 0.43 & $\mathrm{Na}$ & 0.48 & $\mathrm{pH}$ & 0.42 & $\mathrm{SO}_{4}$ & 0.72 \\
\hline $\mathrm{NH}_{4}$ & -0.53 & $\mathrm{pH}$ & 0.49 & $\mathrm{EC}$ & 0.36 & & & & & $\mathrm{Na}$ & 0.39 & $\mathrm{EC}$ & 0.59 \\
\hline $\mathrm{EC}$ & -0.49 & $\mathrm{SO}_{4}$ & -0.41 & $\mathrm{NH}_{4}$ & 0.34 & & & & & & & $\mathrm{pH}$ & -0.53 \\
\hline $\mathrm{SO}_{4}$ & -0.40 & $\mathrm{Ca}$ & -0.35 & & & & & & & & & $\mathrm{NH}_{4}$ & 0.44 \\
\hline In-N & -0.37 & & & & & & & & & & & In-N & 0.38 \\
\hline
\end{tabular}
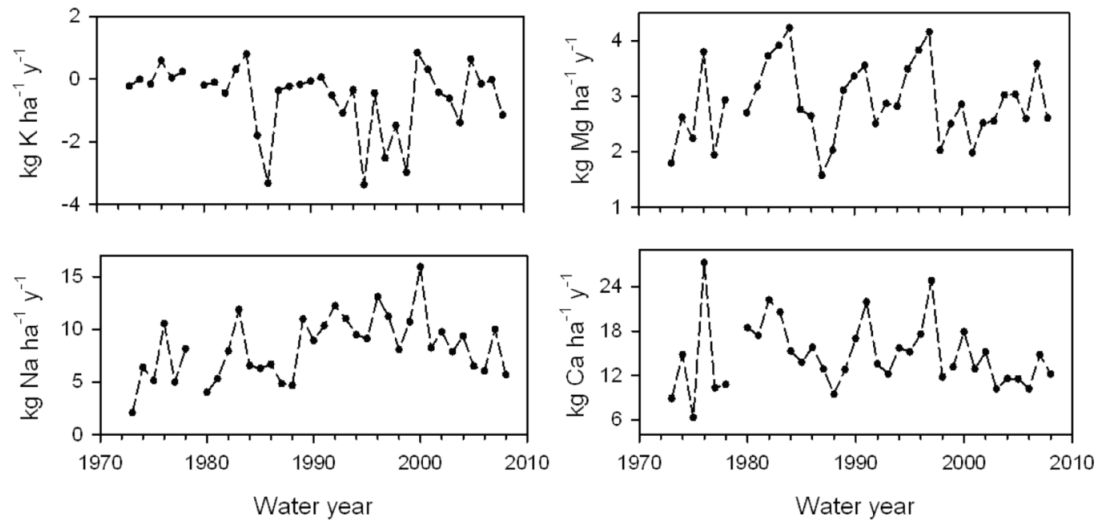

Fig. 10. Annual net outflows (streamwater ouput - precipitation input) of $\mathrm{K}, \mathrm{Na}, \mathrm{Mg}$, and $\mathrm{Ca}$ in East Ck streamwater for the 1971-72 (1972) to 2007-08 (2008) water years.

Most of the $\mathrm{N}$ and $\mathrm{SO}_{4}$ in bulk precipitation was not of sea origin, but most likely of anthropogenic origin, as natural dust in the air in this moist climate region is minimal and pollen is only present for a short time during the year. Neither dust nor pollen is likely to be present from October through March, when approximately $70 \%$ of the annual precipitation falls. In the Seymour watershed, $30 \mathrm{~km}$ west of the study area and closer to salt water, sea salt deposition accounted for $49 \%$ of the $\mathrm{SO}_{4}$ in bulk precipitation, but still a negligible amount of the $\mathrm{NO}_{3}$, based on calculations using data in Zeman \& Slaymaker (1978). Further south in an area adjacent to the ocean in northern Washington, Edmonds et al. (1998) found sea salt contribution to $\mathrm{SO}_{4}$ in bulk precipitation decreased from $70 \%$ at $4 \mathrm{~km}$ from the ocean only to $68 \% 31 \mathrm{~km}$ from the ocean. The Seymour watershed is approximately $20 \mathrm{~km}$ from a large body of salt water, while the study area is approximately $50 \mathrm{~km}$ from this salt water and $180 \mathrm{~km}$ from the nearest ocean water. The relatively low contribution of sea salt to precipitation in the study area can be attributed to its distance from ocean water.

Trends in bulk precipitation chemistry - declines in $\mathrm{SO}_{4}$ from 1980 to the mid 1990s, and less clear trends in $\mathrm{NO}_{3}$ in the study area, accompanied by increases in N/S ratios, are consistent with trends reported elsewhere in the northern hemisphere, including the adjacent US (e.g., Likens et al. 1996; Henriksen et al. 1997; Clow \& Mast 1999; Nilles \& Conley 2001; Schindler et al. 2006; Rogora 2007). Since the decline in excess $\mathrm{SO}_{4}$ concentrations with time has been identical to that of the measured annual $\mathrm{SO}_{4}$ concentrations, and the sea salt contribution to precipitation $\mathrm{SO}_{4}$ has not exhibited any consistent trend with time, the decline in $\mathrm{SO}_{4}$ concentrations in precipitation is likely due to declining anthropogenic contributions to $\mathrm{SO}_{4}$ in the atmosphere.

In the relatively unpolluted Olympic Peninsula of western Washington, however, precipitation chemistry has not exhibited the same trends as in more polluted areas (Edmonds \& Blew 1997). Few statistically significant trends were found from 1984 to 1993 in precipitation chemistry in the Olympic Peninsula, although $\mathrm{NO}_{3}$ concentrations were found to decrease slightly with time (Edmonds \& Blew 1997).

The decline in precipitation $\mathrm{NO}_{3}$ fluxes in East Ck. watershed since the late 1990s is noteworthy and is likely to decrease precipitation $\mathrm{N}$ loads to below critical levels. Critical loads have been defined as "the quantitative estimate of an exposure to one or more pollutants below which harmful effects on specified sensitive elements of the environment do not occur according to present knowledge" (Nilsson \& Grennfelt 1988). They 
have been estimated by determining the loads in precipitation of different chemicals, primarily $\mathrm{N}$ and $\mathrm{S}$, at which a variety of terrestrial and aquatic parameters become adversely affected by those chemicals. Critical precipitation $\mathrm{N}$ loads have been shown to vary, depending on $\mathrm{SO}_{4}$ loads and bedrock type, but for acid igneous rocks, typical of the bedrock in much of the southern Coast Mountains of British Columbia, including the present study area, critical $\mathrm{N}$ loads have usually been in the range of $5-15 \mathrm{~kg} \mathrm{~N} \mathrm{ha}^{-1} \mathrm{y}^{-1}$, decreasing as $\mathrm{SO}_{4}$ loads increase (e.g., Brydges \& Summers 1989; Schulze et al. 1989; Arp et al. 1996), although critical loads as low as $3.8 \mathrm{~kg} \mathrm{~N} \mathrm{ha}^{-1} \mathrm{y}^{-1}$ have been found for a watershed in Norway (Henriksen et al. 1997), and critical wet deposition loads of $4.2 \mathrm{~kg} \mathrm{~N} \mathrm{ha}^{-1} \mathrm{y}^{-1}$ have been suggested for North America (Stoddard 1994) and $4 \mathrm{~kg}$ inorganic-N ha ${ }^{-1} \mathrm{y}^{-1}$ for an area in Colorado (Williams $\&$ Tonnessen 2000). Based on the nature of the bedrock and the relatively high $\mathrm{SO}_{4}$ deposition in the study area, critical $\mathrm{N}$ loads are likely to be closer to the lower end (4-5 kg N ha $\mathrm{y}^{-1}$ ) of the scale. Inorganic $\mathrm{N}$ loads exceeding $4 \mathrm{~kg} \mathrm{ha}^{-1} \mathrm{y}^{-1}$ have occurred for 20 of the 35 years of study with the two highest measured levels of 7.3 and $7.1 \mathrm{~kg} \mathrm{~N} \mathrm{ha}^{-1} \mathrm{y}^{-1}$ occurring during the 1981/82 and 1996/97 water years, respectively (Fig. 1).

Critical $\mathrm{SO}_{4}$ loads of 7-24 $\mathrm{kg} \mathrm{ha}^{-1} \mathrm{y}^{-1}$ for total deposition and 5-19 kg ha ${ }^{-1} \mathrm{y}^{-1}$ for wet deposition have been derived (Brydges \& Summers 1989), although Arp et al. (1996) considered that critical S levels depend on N levels. Deposition in the study area has been at or above critical levels for $\mathrm{SO}_{4}$ for all years except possibly the 1992/93 water year (Fig. 2) - a year in which it was also below critical levels for $\mathrm{N}$ (Fig. 1). Whether or not precipitation $\mathrm{N}$ or $\mathrm{S}$ loads have adversely affected any sensitive ecosystem components is currently unknown for the study area and adjacent region.

\subsection{Streamwater chemistry}

As with precipitation chemistry, streamwater chemistry also exhibited substantial year-to-year variation, which often obscured any possible consistent temporal trends. This was expected, given the substantial year-toyear variation in precipitation and streamflow (Figs 2 and 6). Seasonal temperatures have also varied yearly. As climate influences terrestrial and aquatic biological, chemical, and physical processes, it is one of the main controlling factors of streamwater chemistry (Feller 2005). East Ck. watershed also has relatively coarse textured shallow soils which have a relatively low ability to buffer climate-induced changes in solution chemistry.

Trends in streamwater chemistry tended to be similar to those in precipitation chemistry and are likely to be influenced by precipitation chemistry in view of the significant correlations between streamwater chemical and precipitation chemical parameters. Better correlations of streamwater $\mathrm{pH}$ and $\mathrm{SO}_{4}$ concentrations with precipitation $\mathrm{pH}$ and $\mathrm{SO}_{4}$ concentrations than of stream- water $\mathrm{NO}_{3}$ concentrations with precipitation $\mathrm{NO}_{3}$ concentrations (Tab. 2) suggests that terrestrial and aquatic physical, chemical, and biological processes have influenced streamwater $\mathrm{NO}_{3}$ outputs to a greater extent than streamwater $\mathrm{SO}_{4}$ outputs. This is consistent with other studies which have found streamwater $\mathrm{NO}_{3}$ response to changing precipitation $\mathrm{NO}_{3}$ levels to be more variable than streamwater $\mathrm{SO}_{4}$ response to changing precipitation $\mathrm{SO}_{4}$ levels (Skjelkvåle et al. 2001; Wright et al. 2001; Clair et al. 2008). The apparent increase in streamwater $\mathrm{NO}_{3}$ fluxes until the late $1990 \mathrm{~s}$ is similar to trends elsewhere in the northern hemisphere where increases in streamwater $\mathrm{NO}_{3}$ were widespread but mainly restricted to the 1980s (Stoddard et al. 1999). Variable streamwater $\mathrm{NO}_{3}$ trends have been attributed to variations in climate (Wright et al. 2001) or to changes in plant or microbe immobilization of $\mathrm{N}$ (Fenn et al. 1998). However, increasing streamwater $\mathrm{NO}_{3}$ fluxes could simply result from forests becoming more leaky of $\mathrm{N}$ as a result of declining plant uptake with age (cf. Vitousek 1977). Rogora (2007) found that streamwater $\mathrm{NO}_{3}$ fluxes in Italy increased after warm periods due to enhanced mineralization and nitrification, whereas Mitchell et al. (1996) reported streamwater $\mathrm{NO}_{3}$ fluxes in the NE U.S. increased after an exceptionally cold winter. In the present study streamwater $\mathrm{NO}_{3}$ fluxes were not significantly correlated with mean air temperatures, so the relationship between climate and streamwater $\mathrm{NO}_{3}$ is unclear.

In contrast to $\mathrm{NO}_{3}$, consistent declines in streamwater $\mathrm{SO}_{4}$ levels since 1980 have been found throughout the northern hemisphere, where they have generally been attributed to declines in precipitation $\mathrm{SO}_{4}$ levels (Clow \& Mast 1999; Skjelkvåle et al. 2001), although they have also been impacted by climate and soil factors (Beall et al. 2001; Eimers et al. 2004).

Streamwater dissolved Si is an index of the extent of geological weathering, although not a perfect one as some weathered $\mathrm{Si}$ is incorporated into secondary clays (White \& Blum 1995). The absence of any significant trend in streamwater dissolved $\mathrm{Si}$ concentrations or fluxes (Fig. 6), together with a similar absence of consistent trends in $\mathrm{Mg}$ and $\mathrm{Ca}$ fluxes, a significant correlation between streamwater $\mathrm{Mg}$ concentrations and dissolved Si concentrations $(r=0.53)$ and no significant correlation between streamwater $\mathrm{Mg}$ concentrations and precipitation $\mathrm{pH}$, suggests that geological weathering has not been greatly affected by declining precipitation acidity. This conclusion must remain tentative as declining streamwater Ca concentrations may be associated with declining precipitation acidity since streamwater $\mathrm{Ca}$ concentrations were significantly negatively correlated with precipitation $\mathrm{pH}(r=-0.33)$. However, streamwater $\mathrm{Na}$ and $\mathrm{Cl}$ concentrations and fluxes appear to have increased. Streamwater $\mathrm{Na}$ is also used as an index of geological weathering (White \& Blum 1995) while weathering can also be an important source of $\mathrm{Cl}$ 
(Peters 1991). Also, substantial year-to-year variations in concentrations and fluxes may have obscured or magnified trends. Consequently, trends in geological weathering rates remain unclear.

Although declining streamwater metallic cation concentrations, particularly $\mathrm{Mg}$ and $\mathrm{Ca}$, have sometimes accompanied declines in precipitation $\mathrm{SO}_{4}$ concentrations (Likens \& Bormann 1995), long term trends in the cation concentrations have often been variable (Clow \& Mast 1999; Stoddard et al. 1999; Beall et al. 2001; Watmough \& Dillon 2003). This may be attributed to stream alkalinity levels and the extent to which stream chemistry is dominated by natural processes (Clow \& Mast 1999; Beall et al. 2001). Streams which have higher alkalinity and whose chemistry is still determined mainly by natural processes are likely to exhibit less change in metallic cation concentrations in response to declining precipitation $\mathrm{SO}_{4}$ concentrations. In the 1980s, East Ck. chemistry was found to be relatively unaffected by the acid precipitation falling on its watershed but to have a relatively low buffer capacity (Feller 1987). Thus, relatively little response of metallic cations to declining $\mathrm{SO}_{4}$ concentrations was expected. Possible slight declines in $\mathrm{Mg}$ and $\mathrm{Ca}$ concentrations could be consistent with the relatively low buffer capacity of the streamwater.

\subsection{Watershed chemical budgets}

The decline in net acid $\mathrm{H}$ inputs into the watershed, beginning around 1990, is consistent with declines in precipitation acidity in impacted areas during this period throughout the northern hemisphere (Stoddard et al. 1999). It can be attributed primarily to decreasing precipitation $\mathrm{H}_{2} \mathrm{SO}_{4}$ levels throughout the 1980s (Clow \& Mast 1999; Nilles \& Conley 2001).

East Ck watershed exhibited net inflows of all forms of $\mathrm{N}$ and acid $\mathrm{H}$, and net outflows of $\mathrm{SO}_{4}$ (Fig. 9), which has been found for other forested watersheds (Stoddard 1994; Likens \& Bormann 1995; Watmough \& Dillon 2003; Clair et al. 2008), including a nearby watershed in SW British Columbia (Zeman \& Slaymaker 1978). It differs, however, from the net inorganic-N and total-N outflows found in a watershed in northwestern Washington which were attributed to unmeasured N-fixation inputs (Edmonds et al. 1995). Nitrogen fixation is unlikely to be significant in East $\mathrm{Ck}$. watershed as only low levels have been found in nearby forests (Cushon \& Feller 1989).

Denitrification, particularly in moist areas, may also be a confounding factor. Denitrification was found to occur in the sediments in and adjacent to East Ck., but was estimated to amount to $<0.1 \mathrm{~kg} \mathrm{~N} \mathrm{ha}^{-1} \mathrm{y}^{-1}$ (M.C. Feller: unpublished data) so is unlikely to significantly influence the watershed $\mathrm{N}$ budget.

Consequently, it can be concluded that East $\mathrm{Ck}$ watershed has exhibited net retention of $\mathrm{N}$, which has been less in recent years. This is unlikely to be due sim- ply to reduced $\mathrm{N}$ inputs in precipitation as streamflow total-N output, as a percentage of the bulk precipitation input, has probably been increasing in recent years (Fig. 11). Declining net $\mathrm{N}$ retention may be due to the watershed becoming $\mathrm{N}$-saturated as a result of continual $\mathrm{N}$ precipitation inputs that were above critical levels for most years. Based on seasonal changes in streamwater $\mathrm{NO}_{3}$ concentrations in relation to those of precipitation $\mathrm{NO}_{3}$ concentrations, it is likely that East $\mathrm{Ck}$ watershed shifted from a Stage 0-Stage 1 transition in the early 1970s to a Stage 1-Stage 2 transition over a period of 20-25 years, using the $\mathrm{N}$ saturation stages of Stoddard (1994).

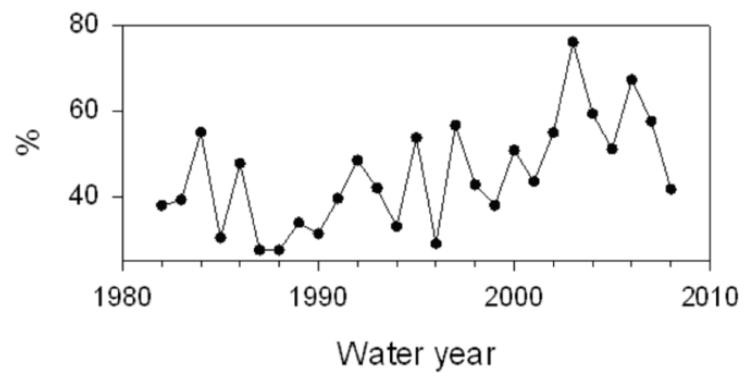

Fig. 11. Annual values of East $\mathrm{Ck}$. streamwater total-N flux expressed as a percentage of the Precipitation total-N flux for the 1981-82 (1982) to 2007-08 (2008) water years.

Declining net $\mathrm{N}$ retention may also be a response to some unknown factor involving biota or climate. Mean water year annual air temperatures rose steadily until the mid 2000s, but subsequently declined to the extent that the last year of record, 2007-08, had the $4^{\text {th }}$ lowest such temperature since the study began. This suggests that climate factors might be influencing net $\mathrm{N}$ outflows, but the lack of significant correlations between mean annual or seasonal air temperatures and all $\mathrm{N}$ concentrations measured, makes this suggestion uncertain.

It is also noteworthy that the study started during a cool phase of the Pacific Decadal Oscillation (PDO) which stopped in 1976. After this followed a warm phase of the PDO which stopped in 1998, to be replaced by a cool phase again (Kiffney et al. 2002). East Ck annual discharge and air temperature were positively related to the PDO (Kiffney et al. 2002), so allowing for a time lag after a change in the PDO phase, it is possible that $\mathrm{N}$ budgets have responded to shifts in the PDO. Further work and additional years of data are required to explain recent trends in $\mathrm{N}$ budgets, however.

Sulphate fluxes in streamwater, in relation to sulphate fluxes in precipitation, have been shown to depend on soil type and presence or absence of the last glaciation (Rochelle et al. 1987). The general net outflow of $\mathrm{SO}_{4}$ from the study watersheds is consistent with data across North America showing that watersheds with Podzol soils and glacial parent material, such as those in the study area, exhibit net outflows of $\mathrm{SO}_{4}$ 
(Rochelle et al. 1987). The significant correlations between streamwater $\mathrm{SO}_{4}$ concentration and precipitation $\mathrm{SO}_{4}$ concentration and acidity (Tab. 2) suggest that precipitation $\mathrm{SO}_{4}$ is influencing watershed net $\mathrm{SO}_{4}$ outflows, as was found by Zeman \& Slaymaker (1978) for the nearby Jamieson Ck. watershed. However, the S chemistry of a stream in northwestern Washington was considered to be influenced dominantly by bedrock weathering and less strongly by precipitation chemistry (Edmonds et al. 1995; Edmonds \& Blew 1997). Fluctuations in $\mathrm{SO}_{4}$ uptake by vegetation and/or release from geological weathering or organic-S complexes, which depend on factors other than just precipitation quantity, or differences in unmeasured dry deposition, can explain differences between $\mathrm{SO}_{4}$ fluxes in precipitation, and those in streamwater.

Continual net outflows of dissolved $\mathrm{Si}$ and $\mathrm{Na}, \mathrm{Mg}$, and $\mathrm{Ca}$ have generally occurred elsewhere in North America (Likens \& Bormann 1995; Beall et al. 2001; Watmough \& Dillon 2003). This has generally been attributed to geological weathering inputs into watersheds and losses of these elements from the soil, which is likely to be the case in East Ck. watershed as well. Potassium exhibited some net inflows and some net outflows in East Ck. watershed, as it also has in other North American watersheds (Likens \& Bormann 1995; Watmough \& Dillon 2003). Although this variability has been linked to variation in precipitation quantity (Likens \& Bormann 1995), such a link was not obvious at East Ck., as the net $\mathrm{K}$ flux was not correlated with precipitation amount, unlike net dissolved $\mathrm{Si}, \mathrm{Na}, \mathrm{Mg}$, and $\mathrm{Ca}$ fluxes. Over the entire study period, the average net input of $\mathrm{K}$ of $0.6 \mathrm{~kg} \mathrm{ha}^{-1} \mathrm{y}^{-1}$ was smaller in magnitude than the values for net dissolved $\mathrm{Si}, \mathrm{Na}, \mathrm{Mg}$, and $\mathrm{Ca}$ fluxes, which is again consistent with other long term North American studies (Likens \& Bormann 1995; Watmough \& Dillon 2003). For East Ck. watershed, the average net inputs of $\mathrm{K}$ are strongly influenced by several years of relatively high precipitation inputs. If the 4 years with the highest precipitation inputs are removed, the average net input of $\mathrm{K}$ decreases to $<0.1 \mathrm{~kg} \mathrm{ha}^{-1} \mathrm{y}^{-1}$, making it similar to that found by Watmough \& Dillon (2003) in Ontario. Differences between net K fluxes and net $\mathrm{Na}, \mathrm{Mg}$, and $\mathrm{Ca}$ fluxes may be associated with variations in watershed biological nutrient fluxes, such as plant uptake, which are generally greater for $\mathrm{K}$ than for the other elements in the study area and elsewhere (Feller \& Kimmins 1984; Likens \& Bormann 1995).

Chloride has been less studied than the other chemicals in northern hemisphere temperate forests, so few comparisons of long term $\mathrm{Cl}$ budget trends can be made. Data in Shaw et al. (2008) for 1994 to 2004 in the NE U.S. suggest a decline in streamwater and precipitation $\mathrm{Cl}$ concentrations, but budget trends were not reported. Elsewhere in the NE U.S. at Hubbard Brook, however, Lovett et al. (2005) reported a $\mathrm{Cl}$ budget trend identical to that in East $\mathrm{Ck}$. watershed. This trend was attributed to decreased plant uptake of $\mathrm{Cl}$ and subsequent mineralization of soil organic material, resulting in increasing release of $\mathrm{Cl}$ to solution.

In East Ck. watershed, the $\mathrm{Na}$ budget had an identical trend to the $\mathrm{Cl}$ budget. For both $\mathrm{Na}$ and $\mathrm{Cl}$, this is likely due to increasing streamwater fluxes as precipitation fluxes showed no clear temporal trends (Figs 2, 3, 6 , and 8 ). This suggests that the source of the increasing net outflow of both chemicals could be within the watershed, as at Hubbard Brook. The absence of recent measurements of plant uptake in East $\mathrm{Ck}$. watershed or knowledge of trends in dry deposition, however, indicates uncertainty over the source of the increasing outflows.

\section{CONCLUSIONS}

Within the study area, in southwestern British Columbia:

1. There has been considerable yearly variation in concentrations and fluxes of most chemicals in precipitation and streamwater. Temporal trends, when they have occurred, have rarely been consistent for the entire 1972-2008 time period. Trends might be affected by dry deposition that was not measured. Based on bulk deposition, however, the most apparent temporal trends have been:

Precipitation - a decline in electrical conductivity, a decline in $\mathrm{NH}_{4}$, inorganic- $\mathrm{N}$, and total-N concentrations and fluxes since the 1980s, an increase in $\mathrm{pH}$ and decline in acid $\mathrm{H}$ fluxes since $\sim 1990$, and a decrease in $\mathrm{SO}_{4}$ concentrations and fluxes from 1980 until the late 1990s.

Streamwater - an increase in $\mathrm{NO}_{3}$ concentrations and fluxes until the late 1990s, an increase in $\mathrm{pH}$ and decrease in acid $\mathrm{H}$ fluxes since the early 1990s, a decrease in $\mathrm{SO}_{4}$ concentrations and fluxes from $\sim 1980$ until $\sim 2000$, and increases in $\mathrm{Na}$ and $\mathrm{Cl}$ concentrations and fluxes until $\sim 2000$.

2. Critical precipitation $\mathrm{SO}_{4}$ loads have probably been exceeded nearly every year, despite their decline with time, while critical inorganic-N fluxes have probably been exceeded for most of the 36 years of study.

3. East $\mathrm{Ck}$. watershed has continuously experienced net inflows of all forms of $\mathrm{N}$ and acid $\mathrm{H}$, and net outflows of dissolved $\mathrm{Si}, \mathrm{Na}, \mathrm{Mg}$, and $\mathrm{Ca}$. It has usually experienced net outflows of $\mathrm{Cl}$ and $\mathrm{SO}_{4}$ and net inflows of K. Since the early 1980s, there has been a trend towards decreasing net inflows of inorganic forms of $\mathrm{N}$ and total- $\mathrm{N}$. Net acid $\mathrm{H}$ inflows have decreased since the early 1990 s, while net $\mathrm{Na}$ and $\mathrm{Cl}$ outflows increased until $\sim 2000$.

4. Based on trends in precipitation and streamwater $\mathrm{N}$ chemistry, and watershed $\mathrm{N}$ budgets, it appears that East $\mathrm{Ck}$ watershed shifted from a Stage 0 - Stage 1 transition in N saturation (Stoddard 1994) in the early 1970 s to a Stage $1-$ Stage 2 transition in the 
mid to late 1990s. It is currently unknown whether this trend towards increasing $\mathrm{N}$ saturation has reversed since the mid 2000s or has been interrupted by a biotic or climatic factor.

\section{ACKNOWLEDGEMENTS}

Funding for this study has been provided by the University of British Columbia, the government of British Columbia, through various student employment programs, Environment Canada, and the National Science and Engineering Research Council of Canada. J. Walters, D. Munro, P. Sanders, P. Lawson, and staff of the University of B.C. Research Forest at Maple Ridge have provided considerable logistical support. J.P. Kimmins assisted with data collection and analysis and with the early design of the study. Particularly S. Pollock and P. Olanski, as well as E. Pierce, C. Olson, R. Lehmann, A. Pölchen, H. Carre, H. Jones, S. Wharton, B. Ford, H. Schell, and M. Tsze have assisted with data analysis. S. Pollock also assisted with figure preparation.

\section{REFERENCES}

Arp, P.A., T. Oja \& M. Marsh. 1996. Calculating critical S and $\mathrm{N}$ loads and current exceedances for upland forests in southern Ontario, Canada. Can. J. For. Res., 26: 696-709.

Beall, F.D., R.G. Semkin \& D.S. Jeffries. 2001. Trends in the output of first-order basins at Turkey Lakes watershed, 1982-96. Ecosystems, 4: 514-526.

Brydges, T.G. \& P.W. Summers. 1989. The acidifying potential of atmospheric deposition in Canada. Water Air Soil Pollut., 43: 249-263.

Clair, T.A., I.F. Dennis, R. Vet \& H. Laudon. 2008. Longterm trends in catchment organic carbon and nitrogen exports from three acidified catchments in Nova Scotia, Canada. Biogeochem., 87: 83-97.

Clow, D.W. \& M.A. Mast. 1999. Long-term trends in stream water and precipitation chemistry at five headwater basins in the northeastern United States. Water Resour. Res., 35: 541-554.

Cogbill, C.V. \& G.E. Likens. 1974. Acid precipitation in the northeastern United States. Water Resour. Res., 10: 11331137.

Cushon, G.M. \& M.C. Feller. 1989. Asymbiotic nitrogen fixation and denitrification in a mature forest in coastal British Columbia. Can. J. For. Res., 19: 1194-1200.

DeCatanzaro, J.B. \& D. Binkley. 1981. Effects of artificial conifer foliage on collection of precipitation and nutrients in coastal British Columbia. Can. J. For. Res., 11: 457458.

D'Elia, C.F., P.A. Steudler \& N. Corwin. 1977. Determination of total nitrogen in aqueous samples using persulphate digestion. Limnol. Oceanogr., 22: 760-764.

Driscoll, C.T., G.E. Likens \& M.R. Church. 1998. Recovery of surface waters in the northeastern U.S. from decreases in atmospheric deposition of sulphur. Water Air Soil Pollut., 105: 319-329.

Edmonds, R.L. \& R.D. Blew. 1997. Trends in precipitation and stream chemistry in a pristine old-growth forest watershed, Olympic National Park, Washington. J. Amer. Water Resour. Assoc., 33: 781-793.

Edmonds, R.L., T.B. Thomas \& R.D. Blew. 1995. Biogeochemistry of an old-growth forested watershed, Olympic National Park, Washington. Water Resour. Bull., 31: 409419 .
Edmonds, R.L., R.D. Blew, J.L. Marra, J. Blew, A.K. Barg, G. Murray \& T.B. Thomas. 1998. Vegetation patterns, hydrology, and water chemistry in small watersheds in the Hoh River Valley, Olympic National Park. USDI National Park Serv. Science. Monograph NPSD/NRUSGS/NRSM 98/02.

Eimers, M.C., P.J. Dillon \& S.A. Watmough. 2004. Long-term (18-year) changes in sulphate concentrations in two Ontario headwater lakes and their inflows in response to decreasing deposition and climate variations. Hydrol. Process., 18: 2617-2630.

Feller, M.C. 1977. Nutrient movement through western hemlock-western red cedar ecosystems in southwestern British Columbia. Ecology, 58: 1269-1283.

Feller, M.C. 1987. The influence of acid precipitation on stream chemistry in a small forested basin in southwestern British Columbia. Forest Hydrology and Watershed Management, IAHS Publ., 167: 33-47.

Feller, M.C. 2005. Forest harvesting and streamwater inorganic chemistry in western North America: A review. $J$. Amer. Water Resour. Assoc., 41: 785-811.

Feller, M.C. \& J.P. Kimmins. 1979. Chemical characteristics of small streams near Haney in southwestern British Columbia. Water Resour. Res., 15: 247-258.

Feller, M.C. \& J.P. Kimmins. 1984. Effects of clearcutting and slash burning on streamwater chemistry and watershed nutrient loss in southwestern British Columbia. Water Resour. Res., 20: 29-40.

Fenn, M.E., M.A. Poth, J.D. Aber, J.S. Baron, B.T. Bormann, D.W. Johnson, A.D. Lemly, S.G. McNulty, D.F. Ryan \& R. Stottlemyer. 1998. Nitrogen excess in North American ecosystems: predisposing factors, ecosystem responses, and management strategies. Ecol. Appl., 8: 706-733.

Galloway, J.N., W.H. Schlesinger, H. Levy II, A. Michaels \& J.L. Schnoor. 1995. Nitrogen fixation: Anthropogenic enhancement - environmental response. Global Biogeochem. Cycles, 9: 235-252.

Henriksen, A., A. Hindar, D.O. Hessen \& O. Kaste. 1997. Contribution of nitrogen to acidity in the Bjerkreim River in southwestern Norway. Ambio, 26: 304-311.

Kiffney, P.M., J.P. Bull \& M.C. Feller. 2002. Climatic and hydrologic variability in a coastal watershed of southwestern British Columbia. J. Amer. Water Resour. Assoc., 38: 1437-1451.

Likens, G.E. \& F.H. Bormann. 1995. Biogeochemistry of a forested ecosystem. Springer-Verlag, New York: 159 pp.

Likens, G.E., C.T. Driscoll \& D.C. Buso. 1996. Long-term effects of acid rain: response and recovery of a forest ecosystem. Science, 272: 244-246.

Lovett, G.M., K.C. Weathers \& W.V. Sobczak. 2000. Nitrogen saturation and retention in forested watersheds of the Catskill Mountains, New York. Ecol. Appl., 10: 73-84.

Lovett, G.M., G.E. Likens, D.C. Buso, C.T. Driscoll \& S.W. Bailey. 2005. The biogeochemistry of chlorine at Hubbard Brook, New Hamshire, USA. Biogeochem., 72: 191-232.

Martin, C.W. \& R.D. Harr. 1988. Precipitation and streamwater chemistry from undisturbed watersheds in the Cascade Mountains of Oregon. Water Air Soil Pollut., 42: 203-219.

Mitchell, M.J., C.T. Driscoll, J.S. Kahl, G.E. Likens, P.S. Murdoch \& L.H. Pardo. 1996. Climatic control of nitrate loss from forested watersheds in the northeast United States. Environ. Sci. Technol., 30: 2609-2612.

Meidinger, D. \& J. Pojar. 1991. Ecosystems of British Columbia. B.C. Ministry of Forests, Victoria, B.C.: 330 pp.

Nilles, M.A. \& B.E. Conley. 2001. Changes in the chemistry of precipitation in the United States, 1981-1998. Water Air Soil Pollut., 130: 409-414.

Nilsson, J. \& P. Grennfelt (Eds). 1988. Critical loads for sulphur and nitrogen. Miljørapport 1988:15, NORD 1998:097, Nordic Council of Ministers, Copenhagen, Denmark: 418 pp. 
Nizich, S.V., T. Pierce \& W. Hohenstein. 1995. National air pollutant trends. U.S. Environmental Protection Agency, Washington, D.C. EPA-454/R-95-011, 1900-1994

Peters, N.E. 1991. Chloride cycling in two forested lake watersheds in the west-central Adirondack Mountains, New York, U.S.A. Water Air Soil Pollut., 59: 201-215.

Rochelle, B.P., M.R. Church \& M.B. David. 1987. Sulfur retention at intensively studied sites in the U.S. and Canada. Water Air Soil Pollut., 33: 73-83.

Rogora, M. 2007. Synchronous trends in $\mathrm{N}^{-\mathrm{NO}_{3}}$ export from $\mathrm{N}$-saturated river catchments in relation to climate. Biogeochem., 86: 251-268.

Schindler, D.W., P.J. Dillon \& H. Schreier. 2006. A review of anthropogenic sources of nitrogen and their effects on $\mathrm{Ca}-$ nadian aquatic ecosystems. Biogeochem., 79: 25-44.

Schulze, E.-D., W. DeVries, H. Hauhs, K. Rosen, L. Rasmussen, C.-O. Tamm \& J. Nilsson. 1989. Critical loads for nitrogen deposition on forest ecosystems. Water Air Soil Pollut., 48: 451-456.

Shaw, S.B., A.A. Harpold, J.C. Taylor \& M.T. Walter. 2008. Investigating a high resolution, stream chloride time series from the Biscuit Brook catchment, Catskills, NY. J. Hydrol., 348: 245-256.

Skjelkvåle, B.L., J.L. Stoddard \& T. Andersen. 2001. Trends in surface water acidification in Europe and North America (1989-1998). Water Air Soil Pollut., 130: 787-792.

Soil Classification Working Group. 1998. The Canadian System of soil classification. $3^{\text {rd }}$ edition. Agric. and Agri-Food Can. Publ. 1946: 187 pp.

Stoddard, J.L. 1994. Long-term changes in watershed retention of nitrogen. Its causes and aquatic consequences. In: L.A. Baker (Ed.) Environmental chemistry of lakes and reservoir. Adv. in Chem. Series No. 237. Amer. Chem. Soc.: 223-284.

Stoddard, J.L. \& P.S. Murdoch. 1991. Catskill Mountains. In: D.F. Charles (Ed.) Acidic deposition and aquatic ecosystems: regional case studies. Springer-Verlag, New York: 237-271.
Stoddard, J.L., D.S. Jeffries, A Lükewille, T.A. Clair, P.J. Dillon, C.T. Driscoll, M. Forsius, M. Johannessen, J.S. Kahl, J.H. Kellogg, A. Kemp, J. Mannio, D.T. Monteith, P.S. Murdoch, S. Patrick, A. Rebsdorf, B.L. Skjelkvåle, M.P. Stainton, T.Traaen, H. van Dam, K.E. Webster, J. Wieting, \& A. Wilander . 1999. Regional trends in aquatic recovery from acidification in North America and Europe. Nature, 401: 575-578.

Stottlemyer, R. 1997. Stream water chemistry in watersheds receiving different atmospheric inputs of $\mathrm{H}^{+}, \mathrm{NH}_{4}^{+}, \mathrm{NO}_{3}^{-}$, and $\mathrm{SO}_{4}=$. J. Amer. Water Resour. Assoc., 33: 767-779.

Vitousek, P.M. 1977. The regulation of element concentrations in mountain streams in the northeastern United States. Ecol. Monogr., 47: 65-87.

Vitousek, P.M., J.D. Aber, R.W. Howarth, G.E. Likens, P.A. Matson, D.W. Schindler, W.H. Schlesinger \& D.G. Tilman. 1997. Human alteration of the global nitrogen cycle: sources and consequences. Ecol. Appl., 7: 737-750.

Watmough, S.A. \& P.J. Dillon. 2003. Base cation and nitrogen budgets for seven forested catchments in central Ontario, 1983-1999. Forest Ecol. Manage., 177: 155-177.

White, A.F. \& A.E. Blum. 1995. Effects of climate on chemical weathering in watersheds. Geochim. Cosmochim. Acta, 59: 1729-1747.

Williams, M.W. \& K.A. Tonnessen. 2000. Critical loads for inorganic nitrogen deposition in the Colorado Front Range, USA. Ecol. Appl., 10: 1648-1665.

Wright, R.F., C. Alewell, J.M. Cullen, C.D. Evans, A. Marchetto, F. Moldan, A. Prechtel \& M. Rogora. 2001. Trends in nitrogen deposition and leaching in acid-sensitive streams in Europe. Hydrol. Earth System Sci., 5: 299310 .

Zeman, L.J. \& O. Slaymaker. 1978. Mass balance model for calculation of ionic input loads in atmospheric fallout and discharge from a mountainous basin. Hydrol. Sci. Bull., 23: 103-117. 